\title{
PENGARUH PELAYANAN SALES ASISTEN TERHADAP KEPUASAN PELAGGAN PADA PT PASARAYA BLOK M JAKARTA SELATAN
}

\author{
Aan Rahman'; Lutfi Dzulkhan Zakir² \\ 1Fakultas Ekonomi \& Bisnis \\ Universitas Bina Sarana Informatika \\ www.bsi.ac.id \\ aan.rahman@bsi.ac.id \\ ${ }^{2}$ Fakultas Ekonomi \& Bisnis \\ Universitas Bina Sarana Informatika \\ www.bsi.ac.id \\ lup_ok@yahoo.com
}

\begin{abstract}
In this day and age more and more places of shopping, especially malls, offer a wide range of products and services complete with modern technology to pamper consumers accompanied by a variety of competitive and competitive price packages. In buying a product or service, a consumer might detect a deficiency. Consumers do not want products or services, which do not meet quality standards. What determines consumers will be satisfied, or not satisfied with a purchase of both products and services. Consumer satisfaction is a function of how close the consumer's expectation is to a product or service to the perceived quality. Consumers will feel dissatisfied if a product or service is not as expected, consumers will feel satisfied if a product or service is not as expected, and consumers will feel very satisfied if a product or service exceeds expectations. The success or failure of the company depends on the service. Waiters play a very important role, whether the customer has been satisfied or dissatisfied with the service provided by the company with the fulfillment of this, the disaffection complained by the customer does not need to happen to customer satisfaction. The instrument used in this study is a questionnaire while the variable that becomes this study is an independent variable, namely sales assistant service $(X)$ and non-independent variable is customer satisfaction (Y). The results of the study showed that there was an influence of sales assistant service and customer satisfaction, based on the calculation of determination that the authors examined, which produced a value of $17.39 \%$ and the remaining $82.61 \%$ influenced by several other factors not examined by the author
\end{abstract}

Keywords: Service, Customer Satisfaction.

Intisari- Di jaman ini semakin banyak berdirinya tempat-tempat pembelanjaan khususnya Mall yang menawarkan berbagai macam produk dan jasa lengkap dengan teknologi modern untuk memanjakan konsumen disertai dengan penawaran paket harga yang bervariatif dan kompetitif. Dalam membeli suatu produk atau jasa, seorang konsumen mungkin mendeteksi adanya suatu kekurangan. Konsumen tidak menginginkan produk atau jasa, yang tidak memenuhi standar mutu. Apa yang menentukan konsumen akan puas, atau tidak puas tehadap suatu pembelian baik itu produk maupun jasa. Kepuasan konsumen adalah fungsi seberapa dekat harapan konsumen atas suatu produk atau jasa dengan mutu yang dirasakan. Konsumen akan merasa tidak puas jika suatu produk atau jasa tidak sesuai harapan, konsumen akan merasa puas jika suatu produk atau pelayanan tidak sesuai harapan, dan konsumen akan merasa sangat puas jika suatu produk atau jasa melebihi harapan. Berhasil atau tidaknya perusahaan tergantung pada pelayanannya. Pelayan berperan sangat penting, apakah pelanggan telah puas atau tidak puas dengan pelayanan yang diberikan oleh perusahaan tersebut dengan dipenuhinya hal ini maka ketidak puasaan yang dikeluhkan konsumen pelanggan tidak perlu terjadi terhadap kepuasaan pelanggan. Instrumen yang digunakan dalam penelitian ini adalah kuisioner sedangkan variable yang menjadi penelitian ini adalah variable bebas yaitu pelayanan sales asisten $(\mathrm{X})$ dan variable tak bebas adalah kepuasaan pelanggan (Y). Hasil penelitian terdapat adanya pengaruh pelayanan sales asisten dan kepuasaan pelanggan, berdasarkan perhitungan determinasi yang penulis teliti, yang menghasilkan nilai sebesar $17.39 \%$ dan sisanya sebesar $82.61 \%$ di pengaruhi beberapa faktor lainnya yang tidak diteliti penulis

Kata Kunci: Pelayanan, Kepuasan Pelanggan. 


\section{PENDAHULUAN}

Berkembangnya dunia bisnis baik dari instansi maupun swasta memiliki permasalahan yang semakin kompleks, di mana perusahaan harus mampu memiliki daya saing dan harus lebih komperatif lagi dalam menghadapi persaingan jika menginginkan tetap eksis dan berkembang. Tentu kita tidak bisa memandang sebelah mata dengan adanya perubahan-perubahan era tekhnologi yang semakin canggih dan sangat pesat, belum lagi perusahaan harus siap untuk menghadapi persaingan yang pesaingnya tidak hanya dari perusahaan lokal, maupun nasional tetapi harus mampu bersaing dengan perusahaan asing karena kita telah memasuki era globalisasi atau pasar bebas. Dalam hal ini tentunya perusahaan dituntut untuk menjalankan perannya yang lebih terarah, baik dan optimal sehingga memungkinkan perusahaan dalam mencapai visi, misi dan tujuan yang memang telah diterapkan. Selain penggunaan tekhnologi yang modern, perusahaan juga harus memperhatikan menejemen dan Administrasi yang baik.

Perusahaan saat ini tindak hanya berorientasi pada keuntungan tetapi lebih menekankan pada pelayanan dan fasilitas yang memuaskan kepada pelanggan dan pemberi harga yang tepat. Dengan memberikan pelayanan yang prima dan tepat akan membangun citra yang baik dimata konsumen. Dalam menjalankan kegiatan pelayanan, terjadi berbagai macam kondisi dan tuntutan dalam pelaksanaan pelayanan kepada pelanggan.

Apabila pelayanan yang diberikan kurang baik, tidak profesional dan harga yang mahal terlebih lagi dengan fasilitas pendukung yang kurang baik. Tentu hal ini akan membuat konsumen beralih ke pesaing usaha sejenis. Pemberian pelayanan dan fasilitas yang baik oleh suatu perusahaan akan menjadi nilai yang sangat berarti untuk konsumen. Konsumen akan memandang harga sebagai hal kedua, apabila nilai layanan yang diterima memiliki kualitas yang baik.

Pelayanan merupakan suatu proses atau aktivitas yang tidak berwujud dan tidak mengikat dari suatu interaksi antara pihak pemberi jasa untuk dapat memenuhi kebutuhan dan kepuasan pelanggan. Ivancevich, Lorensi, Skinner, dan Crosby dalam Zaenal Mukarom (Nurhadi, 2017) "Pelayanan adalah produk yang tidak kasat mata (tidak dapat diraba) yang melibatkan usaha-usaha manusia dan menggunakan peralatan."

Gronroos dalam Zaenal Mukarom di (Nurhadi, 2017) menjelaskan bahwa "pelayanan adalah aktivitas atau serangkaian aktivitas yang tidak kasat mata (tidak dapat diraba) yang terjadi akibat adanya interaksi antara konsumen dan karyawan hal-hal lain yang disediakan perusahaan pemberi pelayanan yang dimaksudkan untuk memecahkan permasalahan/ pelanggan."

Secara garis besar, tawaran produk bisa didikelompokkkan menurut berbagai kriteri. Salah satunya adalah daya tahan (durability) atau berwujud tidaknya (tangibility) produk bersangkutan. Berdasarkan kriteria in, produk bisa dibedakan menjadi tiga macam, yakni:

1. Barang Tidak Tahan Lama (non durable goods) Barang tidak tahan lama adalah barang berwujud yang biasanya habis dikonsumsi dalam satu atau beberapa kali pemakaian. Umur ekonomisnya maksimum satu tahun. Contohnya pasta gigi, sabun mandi, permen, garam, gula, kapur tulis, rokok, buku tulis, dan sebagainya.

2. Barang Tahan Lama (durable goods)

Barang tahan lama adalah barang berwujud yang biasanya bisa bertahan lama atau berumur ekonomis atau lebih dari sastu tahun. Contohnya anatara lain lemari es, TV, mobil, sepeda motor, komputer, mesin cuci, dan lainlain.

3. Jasa (servie)

Jasa merupakan aktivitas, manfaat, atau kepuasan yang ditawarkan untuk dijual. Contohnya Bengkel reparasi kendaraan bermotor, salon kecantikan, kursus keterampilan, pusat kebugaran, restoran, hotel, rumah sakit, universitas dan lain-lain.

Kepuasan pelanggan telah menjelma menjadi kosa kata wajib bagi setiap organisasi bisnis dan nirlaba,konsultan bisnis, peneliti pemasaran, eksekutif bisnis dan konteks tertentu, para birokrat dan politisi.konsep ini hampir selalu hadir di buku teks standar yang mengupas strategi bisnis dan pemasaran. Slogan dan motto perusahaan juga menyinggungnya. Ukuran kinaerja bisnis pun demikian. Ini sebetulnya tidaklah mengherankan karena hasil studi kesinambungan dibidang pemasaran menunjukkan bahwa kepuasan pelanggan berkaitan erat dengan ukuran-ukuran kinerja finansial, seperti marjin operasi, Return On Invesment (ROI), dan laba akuntansi. Kepuasan pelanggan berpengaruh signifikan terhadap shareholder value, walaupun dampaknya bervariasi antar industri dan antar perusahaan.

Lebih lanjut, kepuasan pelanggan juga berpotensi memberikan sejumlah manfaat spesifik, diantaranya: (1) berdampak positif terhadap loyalitas pelanggan; (2) berpotensi menjadi sumber pendapatan masa depan, terutama melalui pembelian ulang, cross-selling; (3) menekan biaya trnsaksi pelanggan di masa depan, terutama biayabiaya komunikasi pemasaran, penjualan, dan 
layanan pelanggan; (4) menelakan volatilitas dan resiko berkenaan dengan prediksialiran kas masa depan; (5) meningkatkan toleransiharga, terutama kesediaaan pelanggan untuk membayar harga premium dan pelanggan cenderung tidak mudah tergoda untuk beralih pemasok; (6) menumbuhkan rekomendasi gethok positif; (7) pelanggan lebih cenderung reseptif terhadap product-line extension, brand extensions, dan new add-on servise yang ditawarkan perusahaan; serta (8) meningkatkan bargaining power relatif perusahaan terhadap jaringan pemasok, mitra bisnis, dan saluran distribusi.

Lantas apa itu kepuasan? Tak mudah menjawabnya. lebih dari satu dekade lalu, pakar kepuasan pelanggan Richard L. Oliver dalam Fandy Tjiptono di (Sujito, 2011) menegaskan bahwa semua orang paham apa itu kepuasan, tetapi begitu mendefinisikannya, tampaknya tak seorang pun tahu. Seperti halnya konsep-konsep manajemen lainnya, ada begitu banyak definisi yang berkembang untuk kepuasan pelanggan. Sebagai ilustrasi, berikut ini adalah lima di antaranya:

1. Perasaan yang timbul setelah mengevaluasi pengalaman pemakaian produk menurut Woodruff \& Jenkins dalam (Pertiwi, 2017).

2. Respon pelanggan terhadap evaluasi persepsi atas perbedaan antara harapan awal sebelum pembelian(atau standar kinerja lainnya) dan kinerja aktual produk sebagaimana dipersepsikan setelah memakai atau mengkonsumsi produk bersangkutan (Tse \& Wilton, 1988) dalam (Haryeni, 2017)

3. Evaluasi purnabeli keseluruhan yang membandingkan persepsi terhadap kinerja produkd dengan persepsi pra-pembelian (Fornell, 1992) dalam (Novianti, 2015).

4. Ukuran kinerja "produk total" sebuah organisasi dibandingkan serangkaian keperluan pelanggan (custumer requirements) (Hill, Brierley \& MacDougall, 1999) dalam (Sutrisno, 2010)

Tingkat perasaan seseorang setelah membandingkan kinerja (atau hasil) yang ia persepsikan dibandingkan dengan harapannya (Kotler, et al.2004)

\section{BAHAN DAN METODE}

\section{A. Populasi dan Sampel}

Menurut Sugiyono (2012:80) populasi adalah wilayah generalisasi yang terdiri atas: obyek/subyek yang mempunyai kualitas dan karakteristik tertentu yang ditetapkan oleh peneliti untuk dipelajari dan kemudian ditarik kesimpulannya. Menurut Sugiyono dalam (Kusnadi, 2016) bagian dari jumlah dan karakteristik yang dimiliki oleh populasi. Bila populasi besar, dan peneliti tidak mungkin mempelajari semua yang ada pada populasi, misalnya karena keterbatasan dana, tenaga dan waktu, maka penelitian dapat menggunakan sampel yang di ambil dari populasi itu.

\section{B. Metode penentuan sampel}

Metode pengambilan sampel yang digunakan dalam penelitian ini adalah sampel random sampling yaitu metode penarikan sampel probabilitas dilakukan secara acak sederhana dan setiap responden memiliki kemungkinan yang sama untuk terpilih sebagai responden. Dalam penelitian ini berjumlah 50 orang. Dengan mengasumsikan populasinya adalah rata-rata maka penetapan jumlah sampel tersebut menggunakan rumus Slovin Azhari seperti berikut:

$\mathrm{n}=\frac{N}{1+\left\{N(e)^{2}\right\}}$

\section{Keterangan:}

$\mathrm{n}=$ Jumlah Sampel

$\mathrm{N}=$ Jumlah populasi

$1=$ Konstanta

$e=$ Kesalahan yang masih dapat ditoleransi

Berdasarkan rumusan tersebut dapat dihitung besar sampel sebagai berikut:

$\mathrm{n}=$ Jumlah sampel yang akan dicari

$\mathrm{n}=50$

$1=$ Konstanta

$e=5 \%$ atau 0.05

$\mathrm{n}=\frac{\mathrm{N}}{1+\left\{\mathrm{N}(\mathrm{e})^{2}\right\}}$

$\mathrm{n}=\frac{50}{1+\left\{50(0.05)^{2}\right\}}$

$\mathrm{n}=\frac{50}{1+\{50(0.005)\}}$

$\mathrm{n}=\frac{50}{1,25}$

$\mathrm{n}=40$

Jumlah sampel yang diperoleh berdasarkan perhitungan di atas adalah sebanyak 40 orang responden.

\section{Perhitungan Data}

\section{Koefisien Korelasi}

Untuk dapat memberikan interprestasi seberapa kuat hubungan antara variable $\mathrm{X}$ dan variable Y maka di gunakan analisis korelasi product moment denga rumus sebagai berikut:

$r_{x y}=\frac{n \cdot \sum x y-\left(\sum x\right)\left(\sum y\right)}{\sqrt{\left\{\sum x^{2}-\left(\sum x\right)\right\}\left\{N \sum y^{2}-\left(N \sum y\right)^{2}\right\}}}$

Keterangan :

$\mathrm{r}_{\mathrm{xy}}$ : koefisien korelasi antara X dan Y 
$\mathrm{n}$ : jumlah responden

$\mathrm{x}$ : variable bebas ( pelayanan)

$\mathrm{y}$ : variable terikat ( kepuasan pelanggan )

$\sum \mathrm{x}$ : jumlah kuadrat seluruh skor $\mathrm{X}$

$\sum y$ : jumlah kuadrat seluruh skor Y

Untuk dapat memberikan interprestasi seberapa kuat hubungan itu, maka dapat digunakan pedoman seperti berikut ini:

Tabel 1. Interprestasi nilai koefisien korelasi

\section{Interval Koefisien}

\begin{tabular}{ll}
\hline $0,00-0,19$ & Sangat Rendah \\
\hline $0,20-0,39$ & Rendah \\
\hline $0,40-0,59$ & Sedang \\
\hline $0,60-0,79$ & Kuat \\
\hline $0,80-1,00$ & Sangat Kuat \\
\hline Sumber: (Sugiyono, 2015)
\end{tabular}

Semakin tinggi koefisien korelasi (r) antara dua variabel, maka tingkat keeratan pengaruh antara dua variabel semakin tinggi dan sebaliknya. Koefisien korelasi digunakan untuk mengetahui pengaruh antara dua variabel yaitu:

Tanda positif $(+)$ pada nilai $r$ menunjukkan pengaruh yang searah artinya apabila nilai $\mathrm{x}$ naik maka y juga akan ikut naik dan sebaliknya.

Tanda negatif (-) pada nilai $r$ menunjukkan pengaruh yang berlawannan artinya apabila nilai $x$ naik maka y turun dan sebaliknya.

\section{Koefisien Determinasi}

Koefisien determinasi adalah bagian dari keragaman total variabel $\mathrm{X}$ (terikat) yang dapat diterangkan atau diperhitungkan oleh keragaman variabel Y (bebas) yaitu koefisien yang mengatur besarnya presentase kontribusi X terhadap Y (J. Suprapto 2008:5) dalam (Ahidin \& Triyono, 2014).

Untuk mengetahui berapa besar pengaruh pelayanan terhadap kepuasan pelanggan digunakan rumus koefisien determinasi sebagai berikut:

$\mathrm{KD}=\mathrm{r} 2 \times 100 \%$

\section{Persamaan Regresi}

Uji signifikan ini untuk menguji variabel bebas dalam regresi memiliki pengaruh atau tidak secara terpisah terhadap variabel terikat.

Uji signifikan ini menggunakan rumus uji t yaitu:

$\mathrm{t}=\frac{\mathrm{r}_{\mathrm{xy}} \sqrt{\mathrm{n}-2}}{\sqrt{1-\mathrm{r} 2}}$

Keterangan:

$\mathrm{t}$ : nilai uji $\mathrm{t}$

$r$ : koefisien korelasi $\mathrm{n}$ : banyaknya sampel

dengan perumusan hipotesisnya adalah:

$\mathrm{H}_{0}$ : Tidak terdapat pengaruh yang sugnifikan antara variabel pelayanan dengan kepuasan konsumen.

$\mathrm{H}_{\mathrm{a}}$ : Terdapat pengaruh yang signifikan antara variabel pelayanan dengan kepuasan pelanggan.

\section{HASIL DAN PEMBAHASAN}

Ruang lingkup atau batasan permasalahan yang akan dibahas dalam penulisan Jurnal ini, yaitu : Penulis hanya akan membahas tentang hubungan pelayanan terhadap kepuasan konsumen dan besarnya pengaruh pelayanan sales asisten terhadap kepuasan pelaggan pada PT. Pasarraya Blok M Jakarta Selatan. Sampel dalam penelitian ini mengguakan sampling jenuh dan menggunakan metode berdasarkan teori dalam (Sugiyono, 2012) untuk penelitian ukuran sampel yang layak adalah antara $20 \mathrm{~s} / \mathrm{d}$ 500. Sampel yang penulis ambil sebanyak 40 responden

\section{A. Karakteristik Responden}

Karakteristik responden yang didapatkan berdasar kusioner adalah sebagai berikut :

Tabel 2. Distribusi Frekuensi berdasarkan jenis kelamin

\begin{tabular}{llcc}
\hline No & Jenis Kelamin & $\begin{array}{c}\text { Frekuensi } \\
\text { (orang) }\end{array}$ & $\begin{array}{c}\text { Persentase } \\
\text { (\%) }\end{array}$ \\
\hline 1 & Laki-laki & 23 & $57.5 \%$ \\
\hline 2 & Wanita & 17 & $42.5 \%$ \\
\hline \multicolumn{2}{l}{ Total } & $\mathbf{4 0}$ & $\mathbf{1 0 0 \%}$ \\
\hline
\end{tabular}

Sumber : (Rahman \& Zakir, 2019)

Mayoritas responden adalah laki-laki dengan jumlah 23 orang atau sebanyak 57.5\%. Sedangkan responden perempuan sebanyak 17 orang atau $42.5 \%$.

Tabel 3. Distribusi Frekuensi berdasarkan usia

\begin{tabular}{lccc}
\hline No & Usia & $\begin{array}{c}\text { Frekuensi } \\
\text { (orang) }\end{array}$ & $\begin{array}{c}\text { Persentase } \\
\text { (\%) }\end{array}$ \\
\hline 1 & $20-30$ & 8 & $20 \%$ \\
\hline 2 & $31-40$ & 17 & $42.5 \%$ \\
\hline 3 & $41-50$ & 12 & $30 \%$ \\
\hline 4 & $>51$ & 3 & $7.5 \%$ \\
\hline Total & & $\mathbf{4 0}$ & $\mathbf{1 0 0 \%}$
\end{tabular}

Sumber : (Rahman \& Zakir, 2019)

Usia dalam penelitian ini berkisar antara 20-50 tahun. Peneliti mengelompokkan usia responden menjadi 4 spesifikasi, yakni usia 20-30 tahun, usia 31-40 tahun, usia 41-50 tahun, dan usia diatas 51 tahun keatas. Mayoritas responden berusia antara 31-40 tahun yakni 17 orang atau 42.5\%. jumlah 
paling sedikit terdapat pada usia 51 tahun keatas, yakni 3 orang atau $7.5 \%$.

Tabel 4. Distribusi Frekuensi Berdasarkan Pekerjaan

\begin{tabular}{clcc}
\hline No & Pekerjaan & $\begin{array}{c}\text { Frekuen } \\
\text { si } \\
\text { (orang) }\end{array}$ & Prosentase \\
\hline 1 & $\begin{array}{l}\text { Belum } \\
\text { bekerja }\end{array}$ & 0 & $0 \%$ \\
\hline 2 & Swasta & 19 & $47.5 \%$ \\
\hline 3 & $\begin{array}{l}\text { Pegawai } \\
\text { Negeri }\end{array}$ & 0 & $0 \%$ \\
\hline 4 & $\begin{array}{l}\text { Pelajar/maha } \\
\text { siswa }\end{array}$ & 0 & $0 \%$ \\
\hline 5 & Wiraswasta & 13 & $32.5 \%$ \\
\hline 6 & Pensiunan & 0 & $0 \%$ \\
\hline 7 & Lain-lain & 8 & $20 \%$ \\
\hline & Total & $\mathbf{4 0}$ & $\mathbf{1 0 0 \%}$ \\
\hline Sum &
\end{tabular}

Sumber : (Rahman \& Zakir, 2019)

Pada karakteristik responden untuk pekerjaan, peneliti membagi jenis pekerjaan responden menjadi tujuh spesifikasi yakni belum bekerja, swasta, pegawai negeri, pelajar/mahasiswa, wiraswasta, dan lain-lain. Jumlah responden terbanyak memiliki pekerjaan yakni swasta 19 orang atau $47.5 \%$ dan yang paling sedikit adalah untuk pekarjaan yakni lain-lain 8 orang atau $20 \%$.

Tabel 5. Distribusi Frekuensi Pengeluaran Belanja per Bulan

\begin{tabular}{clcc}
\hline No & $\begin{array}{l}\text { Pengeluara } \\
\text { n Belanja } \\
\text { (per bulan) }\end{array}$ & $\begin{array}{c}\text { Frekuensi } \\
\text { (orang) }\end{array}$ & $\begin{array}{c}\text { Persenta } \\
\text { se } \\
\mathbf{( \% )}\end{array}$ \\
\hline 1 & $<1.000 .000$ & 0 & $0 \%$ \\
\hline 2 & $\begin{array}{l}1.000 .000- \\
3.000 .000\end{array}$ & 30 & $75 \%$ \\
\hline 3 & $\begin{array}{l}3.000 .000- \\
5.000 .000\end{array}$ & 6 & $15 \%$ \\
\hline 4 & $>5.000 .000$ & 4 & $10 \%$ \\
\hline Total & $\mathbf{4 0}$ & $\mathbf{1 0 0 \%}$ \\
\hline
\end{tabular}

Sumber : (Rahman \& Zakir, 2019)

Pada karakteristik ini reponden melakukan pengeluaran belanja Rp 1.000.000 - Rp 3.000.000 yakni 75\%, pengeluaran $\mathrm{Rp} 3.000 .000-\mathrm{Rp}$ 5.000 .000 yakni $15 \%$, dan untuk pengeluaran belanja diatas Rp 5.000.000 yakni 10\%.

\section{B. Uji Validitas}

Uji validitas digunakan untuk menguji pertanyaan maupun pernyataan pada kuisioner yang disebar valid atau tidak. Langkah untuk menguji validitas pernyataan dalam kuesioner pada penelitianini dapat dilihat sebagai berikut dengan menggunakan rumus product moment :

$\mathrm{r}_{\mathrm{X}}=\frac{\mathrm{n} \cdot\left(\sum \mathrm{XXt}\right)-\left(\sum \mathrm{X}\right)\left(\sum \mathrm{Xt}\right)}{\sqrt{\left\{\mathrm{n} \cdot \Sigma \mathrm{X}^{2}-\left(\sum \mathrm{X}\right)^{2}\right\}\left\{\mathrm{n} \cdot \sum \mathrm{Xt}^{2}-\left(\sum \mathrm{Xt}\right)^{2}\right\}}}$

Perhitungan dengan cara membandingkan nilai $r$ hitung dengan $r$ tabel dengan taraf signifikan (kesalahan) 5\%. Bila $r$ hitung lebih besar dari $r$ tabel maka butir pernyataan tersebut dikatakan valid. Untuk mengetahui data yang diperoleh dari hasil penelitian maka dapat diuji dengan menggunakan uji validitas.

$$
\begin{aligned}
& r_{x}=\frac{40.8911-(189)(1877)}{\sqrt{\left\{40.909-(189)^{2}\right\}\left\{40.88549-(1877)^{2}\right.}} \\
& r_{x}=\frac{356440-354753}{\sqrt{\{36360-35721\}\{3541960-3523129}} \\
& r_{x}=\frac{1687}{\sqrt{\{639\}\{18831)}} \\
& r_{x}=\frac{1687}{\sqrt{12033009}}
\end{aligned}
$$

$r_{x}=\frac{1687}{3468}=\mathbf{0 . 4 8 6}$ dan seterusnya sampai butir pertanyaan ke-10

Tabel 6. Rangkuman analisa validitas Variabel pelayanan $(\mathrm{X})$

\begin{tabular}{cccc}
\hline \multirow{2}{*}{ Pernyataan } & \multicolumn{3}{c}{ Pelayanan (X) } \\
\cline { 2 - 4 } & $\begin{array}{r}\mathbf{r} \\
\text { hitung }\end{array}$ & $\begin{array}{c}\text { table } \\
\text { Ket }\end{array}$ \\
\hline 1 & 0.486 & 0.305 & Valid \\
\hline 2 & 0.554 & 0.305 & Valid \\
\hline 3 & 0.522 & 0.305 & Valid \\
\hline 4 & 0.699 & 0.305 & Valid \\
\hline 5 & 0.399 & 0.305 & Valid \\
\hline 6 & 0.458 & 0.305 & Valid \\
\hline 7 & 0.503 & 0.305 & Valid \\
\hline 8 & 0.652 & 0.305 & Valid \\
\hline 9 & 0.661 & 0.305 & Valid \\
\hline 10 & 0.352 & 0.305 & Valid \\
\hline
\end{tabular}

Sumber : (Rahman \& Zakir, 2019)

Dari tabel di atas dapat dilihat bahwa dari nilai keseluruhan koefisien korelasi ( $r$ hitung) memiliki nilai yang lebih besar dari pada ( $r$ tabel). Dapat disimpulkan bahwa ke 10 butir pertanyaan tersebut adalah valid karena $r$ hitung $>$ dari nilai $r$ tabel untuk $\mathrm{N}=40$ yaitu sebesar 0.305 . Butir yang memiliki validitas tertinggi adalah butir yang ke empat yaitu sebesar 0.699. Dan ke sembilan yaitu sebesar 0.661 .

2. Uji Reliabilitas Variabel Pelayanan (X) 
$\mathrm{Si}=\frac{\sum \mathrm{Xi} 2-\frac{\left(\sum \mathrm{Xi}\right) 2}{\mathrm{n}}}{\mathrm{n}}$

Contoh perhitungan butir 1

$\mathrm{Si}_{1}=\frac{909-\frac{(189) 2}{40}}{40}=\frac{909-\frac{(35721)}{40}}{40}=\frac{909-893.03}{40}=0.399$

Total Varian score tiap butir pertanyaan $=4.257$

$\mathrm{St}=\frac{\sum \mathrm{Xi} 2-\frac{\left(\sum \mathrm{Xi}\right) 2}{\mathrm{n}}}{\mathrm{n}}$

$\mathrm{St}=\frac{88549-\frac{(1877) 2}{40}}{40}$

St $=\frac{88549-\frac{3523129}{40}}{40}$

$\mathrm{St}=\frac{88549-88078}{40}$

St $=\frac{471}{40}$

$\mathrm{St}=11.79$

$\mathrm{r}=\left(\frac{\mathrm{k}}{\mathrm{k}-1}\right)\left(1-\frac{\sum \mathrm{Si}}{\mathrm{St}}\right)$

$r=\left(\frac{10}{10-1}\right)\left(1-\frac{4.257}{11.769}\right)$

$\mathrm{r}=(1.1111)(0.6383)$

$\mathrm{r}=0.709$

(Reliabel karena nilai $r$ hitung lebih kecil dari pada $r$ tabel product moment yaitu $0.709>0.305$ ). product moment :

$\mathrm{r}_{\mathrm{y}}=\frac{\mathrm{n} \cdot\left(\sum \mathrm{YYt}\right)-\left(\sum \mathrm{Y}\right)\left(\sum \mathrm{Yt}\right)}{\sqrt{\left\{\mathrm{n} \cdot \sum \mathrm{Y}^{2}-\left(\sum \mathrm{Y}\right)^{2}\right\}\left\{\mathrm{n} \cdot \sum \mathrm{Yt}^{2}-\left(\sum \mathrm{Yt}\right)^{2}\right.}}$

Perhitungan dengan cara membandingkan nilai $t$ hitung dengan $\mathrm{t}$ tabel dengan taraf signifikan (kesalahan) 5\%. Bila $r$ hitung lebih besar dari $r$ tabel maka butir pernyataan tersebut dikatakan valid. Untuk mengetahui data yang diperoleh dari hasil penelitian maka dapat diuji dengan menggunakan uji validitas.

$$
\begin{aligned}
& r_{y}=\frac{40.8607-(188)(1824)}{\sqrt{\left\{40.896-(188)^{2}\right\}\left\{40.83522-(1824)^{2}\right\}}} \\
& r_{y}=\frac{344280-342912}{\sqrt{\{35840-35344\}\{3340880-3326976\}}} \\
& r_{y}=\frac{1368}{\sqrt{\{496\}\{13904\}}} \\
& r_{y}=\frac{1368}{\sqrt{6896384}} \\
& r_{y}=\frac{1368}{2626,1}=\mathbf{0 . 5 2 1 d a n ~ s e t e r u s n y a ~ s a m p a i ~ b u t i r ~} \\
& \text { pertanyaan ke-10 }
\end{aligned}
$$

Tabel 7. Rangkuman analisa validitas Variabel Kepuasan Pelanggan(Y)

\begin{tabular}{cccc}
\hline \multirow{2}{*}{ Pernyataan } & \multicolumn{3}{c}{ Kepuasan Pelanggan (Y) } \\
\cline { 2 - 4 } & r hitung & r tabel & Ket \\
\hline 1 & 0,521 & 0,305 & Valid \\
\hline 2 & 0,521 & 0,305 & Valid \\
\hline 3 & 0,521 & 0,305 & Valid \\
\hline
\end{tabular}

\begin{tabular}{cccc}
\hline 4 & 0,521 & 0,305 & Valid \\
\hline 5 & 0,521 & 0,305 & Valid \\
\hline 6 & 0,521 & 0,305 & Valid \\
\hline 7 & 0,521 & 0,305 & Valid \\
\hline 8 & 0,521 & 0,305 & Valid \\
\hline 9 & 0,521 & 0,305 & Valid \\
\hline 10 & 0,521 & 0,305 & Valid
\end{tabular}

Sumber : (Rahman \& Zakir, 2019)

Dari tabel di atas dapat dilihat bahwa dari nilai keseluruhan koefisien korelasi ( $\mathrm{r}$ hitung) memiliki nilai yang lebih besar dari pada ( $r$ tabel). Dapat disimpulkan bahwa ke 15 butir pertanyaan tersebut adalah valid karena $r$ hitung $>$ dari nilai $r$ tabel untuk $\mathrm{N}=92$ yaitu sebesar 0.203. Butir yang memiliki validitas tertinggi adalah butir yang ke dua belas yaitu sebesar 0.657 . Dan ke dua yaitu sebesar 0.647 .

2. Uji Reliabilitas Variabel Kepuasan Pelanggan (Y)

$\mathrm{Si}=\frac{\sum \mathrm{Xi} 2-\frac{\left(\sum \mathrm{Xi}\right) 2}{\mathrm{n}}}{\mathrm{n}}$

Contoh perhitungan butir 1

$\mathrm{Si}_{1}=\frac{896-\frac{(188) 2}{40}}{40}=\frac{896-\frac{(35344)}{40}}{40}=\frac{896-883.6}{40}=0.310$

Total Varian score tiap butir pertanyaan $=4.303$

$$
\begin{aligned}
& \text { St }=\frac{\sum \mathrm{Xt} 2-\frac{\left(\sum \mathrm{Xi}\right) 2}{\mathrm{n}}}{\mathrm{n}} \ldots \ldots \ldots \ldots \ldots \ldots \ldots \ldots \ldots \ldots \\
& \mathrm{St}=\frac{83522-\frac{(1824) 2}{40}}{40} \\
& \mathrm{St}=\frac{83522-\frac{3326976}{40}}{40} \\
& \mathrm{St}=\frac{83522-83174.4}{40} \\
& \mathrm{St}=\frac{347.6}{40} \\
& \mathrm{St}=8.690 \\
& \mathrm{rca}=\left(\frac{\mathrm{k}}{\mathrm{k}-1}\right)\left(1-\frac{\sum \mathrm{Si}}{\mathrm{St}}\right) \\
&=\left(\frac{10}{10-1}\right)\left(1-\frac{4.303}{8.690}\right) \\
&=(1.1111)(1-0.495) \\
&=(1.1111)(0.5048) \\
& \mathrm{rca}=0.561
\end{aligned}
$$

\section{Koefisien Korelasi}

Dalam menganalisa pengaruh pelayanan terhadap kepuasan pelanggan pada PT Pasaraya Tosersajaya, Blok M. Penulis menggunakan metode korelasi sederhana. Dari hasil pengumpulan kuisioner sebanyak 40 responden dengan kuisioner pelayanan (X) dan kepuasan pelanggan (Y) sebanyak 10 pertanyaan . Dari data tersebut, penulis gunakan untuk mengetahui hubungan antara variabel $\mathrm{X}$ (pelayanan) dengan variabel $\mathrm{Y}$ 
(kepuasan pelanggan), dengan menggunakan rumus korelasi sebagai berikut:

$$
\begin{aligned}
\mathrm{r}_{\mathrm{xy}} & =\frac{\mathrm{n} \cdot\left(\sum \mathrm{XYt}\right)-\left(\sum \mathrm{X}\right)\left(\sum \mathrm{Y}\right)}{\sqrt{\left\{\mathrm{n} \cdot \mathrm{X}^{2}-\left(\sum \mathrm{X}\right)^{2}\right\}\left\{\mathrm{n} \cdot \sum^{2}-\left(\sum \mathrm{Y}\right)^{2}\right\}}} \ldots \frac{40 \cdot(85760)-(1877)(1824)}{\sqrt{\left\{40.88549-(1877)^{2}\right\}\left\{40.83522-(1824)^{2}\right\}}} \\
& =\frac{3430400-3423648}{\sqrt{\{3541960-3523129\}\{3340880-3326976\}}} \\
& =\frac{6752}{\sqrt{\{18831\}\{13904)}} \\
& =\frac{6752}{\sqrt{261826224}} \\
& =\frac{6752}{16181.0452} \\
\mathrm{r}_{\mathrm{xy}} & =0.4172 \text { dibulatkan menjadi } 0.417
\end{aligned}
$$

Dari analisis perhitungan menggunakan koefisien korelasi pearson ada hubungan korelasi positive antara pelayanan dengan kepuasan pelanggan, yaitu sebesar $\mathbf{r}=\mathbf{0 . 4 1 7}$ yang termasuk kategori sedang, maka untuk mengetahui seberapa besar pengaruh pelayanan terhadap kepuasan pelanggan adalah dengan menggunakan koefisien determinasi.

\section{Koefisien Determinasi}

Selanjutnya untuk mengetahui seberapa besar pengaruh pelayanan terhadap kepuasan pelanggan dengan menggunakan rumus koefisien penentu atau koefisien determinasi sebagai berikut:

$$
\begin{aligned}
\mathrm{KD}=\mathrm{r} 2 & \times 100 \% \\
= & (0.417)^{2} \times 100 \ldots \ldots \ldots \ldots \\
= & 0.1738 . \ldots \\
= & 17.39 \%
\end{aligned}
$$

Hal ini membuktikan bahwa besarnya pengaruh pelayanan terhadap kepuasan pelanggan sebesar $17.39 \%$ dan sisanya sebesar $82.61 \%$ di pengaruhi beberapa faktor lainnya yang tidak diteliti penulis.

\section{E. Uji Signifikan}

Berdasarkan hasil perhitungan di atas, maka penulis melakukan pengujian hipotesa dengan cara membandingkan nilai $r$ tabel dengan $r$ hitung. Nilai $r$ tabel ditentukan berdasarkan tingkat signifikan yang digunakan dan derajat kebebasan ( $\mathrm{df}=\mathrm{n}-2)$ yang besarnya tergantung dari jumlah sampel (n). taraf nyata yang penulis gunakan sebesar $0.05 \%$ (0.05).

Rumus thitung adalah sebagai berikut:

$t_{\text {hitung }}=\frac{r_{x y \sqrt{n-2}}}{\sqrt{n-r 2}}$

dimana

$\mathrm{t}=$ koefisien korelasi

$\mathrm{n}$ = banyaknya responden

thitung $\frac{0.417 \sqrt{40-2}}{\sqrt{1-(0.417) 2}}=$

$t_{\text {hitung }}=\frac{0.417 \sqrt{38}}{\sqrt{1-0.173889}}$

$t_{\text {hitung }}=\frac{8.448728}{\sqrt{0.826111}}$

$\mathrm{t}_{\text {hitung }}=\frac{15.846}{0.909}$

$t_{\text {hitung }}=17.432$

pengambilan keputusan menggunakan angka pembanding $t$ tabel dengan kriteria sebagai berikut:

jika t hitung $>\mathrm{t}$ tabel $\mathrm{H}_{0}$ di tolak (signifikan) jika $\mathrm{t}$ hitung $<\mathrm{t}$ tabel $\mathrm{H}_{0}$ di terima (tidak signifikan)

Sehingga berdasarkan hasil pengujian rumus di atas maka t hitung $>$ t tabel yaitu: $17.432>\mathbf{1 . 6 8 6}$ yang artinya $\mathrm{H}_{0}$ di terima dan $\mathrm{H}_{1}$ di tolak, artinya pelayanan $(\mathrm{X})$ berpengaruh (signifikan) terhadap tingkat kepuasan pelanggan (Y).

\section{KESIMPULAN}

Berdasarkan hasil penelitian di atas bahwa ada pengaruh pelayanan sales asisten terhadap kepuasaan pelanggan pada PT. Pasaraya Blok M Jakarta Selatan yang menggunakan perhitungan koefisien korelasi yang digunakan dalam penulisan ini menunjukan bahwa besarnya pengaruh pelayanan terhadap kepuasan pelanggan sebesar $17.39 \%$ dan sisanya sebesar $82.61 \%$ di pengaruhi beberapa faktor lainnya yang tidak diteliti penulis.

\section{REFERENSI}

Ahidin, U., \& Triyono. (2014). PENGARUH KUALITAS PELAYANAN TERHADAP KEPUASAN. Jurnal Ilmiah Prodi Manajemen Universitas Pamulang, 2(1).

Haryeni. (2017). KUALITAS PELAYANAN, KEPERCAYAAN DAN KEPUASAN NASABAH DAN PENGARUHNYA TERHADAP LOYALITAS NASABAH PADA TABUNGAN BANK RAKYAT INDONESIA (PERSERO) TBK KANTOR CABANG KHATIB SULAIMAN. Jurnal Ekonomi \& Bisnis Dharma Andalas, 19(2), 189-201. 
Kusnadi, Y. (2016). PARADIGMA Vol. XVIII. No.2 September 2016 PENGARUH KETERIMAAN APLIKASI PENDAFTARAN ONLINE TERHADAP JUMLAH PENDAFTAR DI SEKOLAH DASAR NEGERI JAKARTA, XVIII(2), 89-101.

Novianti, N. (2015). PENGARUH CUSTOMER SATISFACTON DAN SWITCHING BARRIER. SEGMEN-Jurnal Manajemen Dan Bisnis, 11(1B), 1-9.

Nurhadi. (2017). Pengaruh Pelayanan Dan Produk Jasa Terhadap Komitmen Penerimaan Nasabah Pada Bank BRI Tigaraksa. Jurnal Moneter, IV.

Pertiwi, F. (2017). Pengaruh Disiplin Kerja Terhadap Produktivitas Kerja Pegawai Negeri Sipil Di Kantor Dinas Perindustrian Perdagangan Koperasi Dan UMKM Provinsi Kalimantan Timur. EJournal Administrasi Negara, 1.
Rahman, A., \& Zakir, L. D. (2019). Laporan Akhir Penelitian Mandiri: Pengaruh Pelayanan Sales Asisten Terhadap Kepuasan Pelaggan Pada PT Pasaraya Blok M Jakarta Selatan. Jakarta.

Sugiyono. (2012). Metode Penelitian Kuantitatif Kualitatif dan R\&D. Bandung: Aphabeta.

Sugiyono. (2015). Metode Penelitian Kuantitatif Kualitatif Dan R\&D. Bandung: Alfabeta.

Sujito, S. (2011). TOTAL SATISFACTION MERUPAKAN BENTUK DISKONFIRMASI PELANGGAN UNTUK MENINGKATKAN LOYALITAS. In Seminar Nasional Ilmu Ekonomi Terapan (pp. 41-48). Semarang: Fakultas Ekonomi Universitas Muhammadiyah Semarang. Retrieved from https://jurnal.unimus.ac.id/index.php/psn12 012010/article/view/404

Sutrisno. (2010). Manajemen Sumber Daya Manusia. Jakarta: Kencana. 